\title{
1. The war at sea
}

\subsection{INTRODUCTION}

This chapter seeks to illustrate the stock of wrecked vessels, aircraft and objects that comprises the sunken legacy of WWI by setting the losses in their historical context. The chapter does not attempt a history of the war at sea, but does focus on the historical contexts that affect the way in which various legacy wrecks are viewed and the values that they embody; which are discussed in Chapter 2. This chapter introduces the combatant States; the geographical extent of the naval engagements; the nature of the battling fleets; the involvement of the merchant fleet; and the rate and extent of losses, particularly human losses.

\subsection{NAVAL POWER AS A PRECURSOR TO WAR}

For centuries, Britain had ruled the seas and, through this, created an unparalleled empire by the end of the nineteenth century. While other nations, such as the US, France, Russia and Japan had sought to develop and enhance their naval power, none matched that of Britain. For centuries too, Britain had led the world's industrial development and manufacturing output. From the late 1800s, however, Germany had begun a process of rapid industrialisation, particularly from 1890 to 1914 during which it reached and overtook Britain in heavy industry such as steel and coal production. With this industrialisation and growing regional power, Germany sought to expand its influence. It had, however, missed the great colonial scramble that had occurred in the nineteenth century. ${ }^{1}$ Kaiser Wilhelm II came to power in 1888, and took a keen interest in naval affairs, having been greatly influenced in his youth by observing the Royal Navy. In part, the development of the German Imperial Navy

1 Germany did, when war began, have a number of colonies, including German South West Africa (Namibia), German East Africa (Tanzania), Togo, Cameroon, Samoa, New Guinea, Micronesia and the Port of Tsingtao in China. These, however were insubstantial compared with British and French colonies. 
(Kaiserliche Marine) was the Kaiser's desire to impress, and be accepted by, his English relatives. ${ }^{2}$ It was also partly Germany's desire for international influence, and Alfred von Tirpitz's ${ }^{3}$ view that a strong navy was necessary to achieve this. Given its lack of an extensive colonial presence, Germany's desire for greater world influence was manifested through its presence in the only part of the world not subject to State sovereignty - the high seas. But for Germany, this increase in the navy, though unintentional, threatened British interests. Arthur Balfour, former British prime minister, wrote: '[w]ithout a Superior fleet, Britain would no longer count as a power. Without any fleet at all, Germany would remain the greatest power in Europe'. ${ }^{4}$ The Royal Navy alone secured Britain's economy, ensuring not only that food and raw materials entered Britain and that many manufacturing goods left, but also that the City of London remained at the centre of international finance. ${ }^{5}$

The great naval race that followed increased both the number and size of battleships, culminating in the launching of the HMS Dreadnought in 1906. The largest, quickest and most powerful vessel afloat, HMS Dreadnought ${ }^{6}$ was a culmination of vessels designed for visual impact and power where size and might trumped combat effectiveness. ${ }^{7}$ By the middle of 1914, Britain had considerably more vessels, and larger vessels, than the German navy, and together with those of its allies, France, Russian and Japan, the Allies had a numerical advantage over the German and Austro-Hungarian navies of three to one. ${ }^{8}$ Table 1.1 below illustrates the relative sizes of the belligerent navies, though the numbers are debatable given the pace of construction of new vessels and the difficulty in vessel type classification. ${ }^{9}$

2 Robert K Massie, Castles of Steel: Britain, Germany and the Winning of the Great War at Sea (Random House, 2003) 8. See also Robert K Massie Dreadnought: Britain, Germany and the Coming of the Great War (Jonathan Cape 1992).

3 Grand Admiral von Tirpitz is regarded as the creator of the German navy. Massie (n2) 8.

4 Massie (n2) 10.

5 Marcus Faulkner The Great War at Sea: A Naval Atlas 1914-1918 (Seaforth Publishing, 2015) ix.

6 F J Dittmar and J J Colledge An Index to British Warships 1914-1919 $<$ http://www.naval-history.net/WW1NavyBritishShips-Dittmar1.htm\#intro>.

7 Faulkner (n5) viii.

8 Ibid. ix.

9 The table is derived primarily from Faulkner (n5) 3 and Paul G Halpern, A Naval History of World War I (Naval Institute Press, 1994) 7-12. The numbers do differ in many publications, and reflects the difficulty in pinning down a 
Table 1.1 Naval vessels of belligerent countries by type and number

\begin{tabular}{lrrrrrrr}
\hline & Britain & Germany & France & Italy & $\begin{array}{c}\text { Austro- } \\
\text { Hungary }\end{array}$ & Russia & US \\
\hline Dreadnoughts & 35 & 20 & 12 & 6 & 4 & 17 & 14 \\
Pre-dreadnoughts & 40 & 22 & 17 & 8 & 9 & 10 & 23 \\
Cruisers & 101 & 78 & 28 & 21 & 10 & 13 & 44 \\
Destroyers & 221 & 90 & 81 & 33 & 18 & 25 & 50 \\
Submarines & 73 & 31 & 50 & 22 & 5 & 22 & 18 \\
Torpedo & 109 & 115 & 187 & 85 & 70 & 84 & 23 \\
boats & & & & & & & \\
\hline
\end{tabular}

With the British Isles acting as a breakwater between Germany and the open oceans, this supremacy kept the German navy largely confined to harbour, especially as the Kaiser feared the loss of any of Germany's large battleships. ${ }^{10}$ Nevertheless, the German navy had developed into a professional, well-trained force with formidable vessels that considered itself the equal to the Royal Navy in all but numerical advantage.

\subsection{THE NAVAL BATTLES}

The great navies of the belligerent nations met on only a few occasions, and while there were a greater number of smaller fleet actions, for the most part naval actions involved only a handful of ships. The great clashes, such as Jutland, Dogger Bank, Coronel, Falklands and Heligoland Bight led to significant loss of lives, and greatly affected the outcome of the war. The smaller clashes and individual actions too had a significant effect on the war, particularly those that took place in distant waters where fewer and smaller vessels could have a greater impact. This was particularly true, for example, of the German commerce raiders such as the Emden.

Arguably, the first naval action of the war took place within hours of the declaration of war between Britain and Germany being effective on 5 August 2014. The British cable ship Teleconia proceeded to the North Sea, retrieved and cut a number of Germany's overseas cables, severing

number accurately in a time when construction of vessels was in full swing. Older vessels were being decommissioned to make way for newer vessels, and in some States, were being bought, sold and requisitioned.

10 Faulkner (n5) 77. 
direct communication with Spain, France and US. ${ }^{11}$ It has, however also been suggested that the first shot of the war at sea was fired in Australia. Shortly after the announcement that war had been declared, the Norddeutscher Lloyd merchant vessel Pfaltz was leaving the Port of Melbourne. When it was ordered to stop, and failed to do so, a shot was fired from Fort Nepean at the head of the Bay. Though it did not hit the Pfaltz it prevented it from leaving and it was detained. ${ }^{12}$

The first actual naval engagement also took place later on the 5 August when the light cruiser HMS Amphion and the destroyers HMS Landrail and HMS Lance engaged the German auxiliary minesweeper Königin Luise shortly after the latter was observed laying a minefield near the Dover Strait. Firing the first British shot of the war, ${ }^{13}$ HMS Lance, and then HMS Amphion, engaged and sank the Königin Luise, becoming Germany's first loss of the war. ${ }^{14}$ HMS Amphion rescued 75 of the 130 crew. ${ }^{15}$ Ironically, HMS Amphion then became the first British loss of the war when, the following day, it struck one of the mines laid by Königin Luise, and sank with the loss of 132 of its 308 crew as well as all but one of the rescued crew of the Königin Luise. ${ }^{16}$

While small-scale clashes such as this early engagement continued throughout the war at sea, the Admiralty in Britain sought to exert its strength through large-scale naval action involving its Grand Fleet under Admiral John Jellicoe. The German High Seas Fleet, under Admiral Friedrich von Ingehohl, constrained by the Kaiser's aversion to risking the loss of their battleships, nevertheless attempted to reduce Britain's numerical advantage in vessels by a varied strategy that included

11 Massie (n2) 77.

12 The Pflatz was condemned as prize and used as an Australian troopship. Andrew Viduka 'An Overview of Australia's World War I Underwater Cultural Heritage 1914-1924 and Observations on Changing National Expectations to Commemoration in Ulrike Guérin, Arturo Rey Da Silva and Lucas Simmonds The Underwater Cultural Heritage from World War I: Proceedings of the Scientific Conference on the Occasion of the Centenary of World War I (UNESCO, 2015) 164; Faulkner (n5) ix.

13 Anthony Firth 'East Coast War Channels: a landscape approach to battlefield archaeology in the North Sea' (2015) 44(2) Nautical Archaeology 438; Halpern (n9) 27; Faulkner (n5) ix.

14 Wrecksite <http://www.wrecksite.eu/wreck.aspx?9543>.

15 Nicolas Wolz From Imperial Splendor to Internment: the German Navy in the First World War (Naval Institute Press, 2013) 28.

16 Wolz (n15) 28. See also James Goldrick Before Jutland: The Naval War in Northern European Waters, August 1914-February 1915 (Naval Institute Press, 2015) 86-7. 
engagement with lesser vessels, such as cruisers and destroyers, away from the Grand Fleet. These two differing strategies led to a number of clashes.

\subsubsection{The Battle of Heligoland Bight}

The first major clash between the navies of Britain and Germany took place off Heligoland in the North Sea. The British navy wished to draw the German navy out of its base in Wilhelmshaven to engage. What became known as the Battle of Heligoland Bight was devised by Commodore Roger Keyes, commander of the 6th and 8th Submarine Flotillas, and Commodore Reginald Tyrwhitt, commander of the Harwich Flotillas, which consisted of the light cruisers HMS Arethusa and HMS Fearless together with 31 destroyers.

From the beginning of hostilities, Commodore Keyes' submarines had patrolled the waters off Heligoland and had learnt that each evening German light cruisers would escort destroyers out into the bight to patrol against British submarines and minelayers, and were escorted back again at daybreak. Using submarines as bait, the plan was for the Harwich Flotillas to sweep through the bight at dawn catching the German light cruisers and destroyers in the sweep from north to south and then from east to west. ${ }^{17}$ In an early example of poor communication channels in the British navy, the First Lord of the Admiralty, ${ }^{18}$ Winston Churchill, had approved of the plan but had not informed the Commander-in-Chief of the Grand Fleet, Admiral Jellicoe. On learning of the plan at a very late stage in its deployment, Admiral Jellicoe ordered the 1st Battle Cruiser Squadron and 1st Light Cruiser Squadron from Scapa Flow to assist if necessary; fearing that the German High Seas Fleet might come out. Moreover, Commodore Tyrwhitt was only informed of this larger possible participation after the operation had begun, and Commodore Keyes was never informed of the larger naval presence, only becoming aware of their presence during the battle itself by identifying the Grand Fleet vessels through his periscope rather than being told. ${ }^{19}$

The plan was initiated in very foggy conditions which caused significant confusion and complex vessel movements during what has been

\footnotetext{
17 Massie (n2) 98.

18 A ministerial cabinet position held by a politician without any necessary military or naval background.

19 Massie (n2) 99-106; Mike Farquharson-Roberts A History of the Royal Navy: World War I (I B Tauris \& Co, 2014) 50.
} 
described as one of the most difficult battles to follow. ${ }^{20}$ The first contact occurred between HMS Arethusa and Frauenlob with HMS Arethusa being hit 15 times, killing 11 of its crew. ${ }^{21}$ Frauenlob was hit ten times killing five crew and wounding 32, including its captain. ${ }^{22}$ Neither vessel sank. The first vessel lost was the German destroyer $V-187$, with the loss of 24 of its 84 crew. $^{23}$ Because the tide was low, German vessels had difficulty getting out of the Jade River and only destroyers and light cruisers could enter the battle and only one at a time. As they did so, engagements followed. The German light cruiser Mainz was sunk with the loss of 89 of its 497 crew, including its captain. ${ }^{24}$ During the engagement that sank it, Mainz's accurate fire hit the destroyer HMS Laurel three times, HMS Laertes four times and HMS Liberty, killing its captain. $^{25}$ During this phase, however it appeared that the British might be overwhelmed by the increasing numbers of German vessels. The arrival of the 1st Battle Cruiser Squadron and 1st Light Cruiser Squadron then swayed the balance. The German light cruiser Ariadne was sunk by a sustained attack from the battlecruisers HMS Lion and HMS Princess Royal. Of a compliment of 257, only 59 survived the sinking of the Ariadne. The light cruiser Cöln, Admiral Maas' flagship had by then also sustained significant damage and finally sank. Of its compliment of 368, including Admiral Maas, there was only one survivor, stoker Adolf Neumann, who was only rescued two days after its sinking. ${ }^{26}$

British communication channels had been poor leading up to the operation, but were also poor during the operation. Because not all commanders were aware of what vessels were actually taking part in the operation, Commodore Keyes' submarine E6 fired two torpedoes at HMS Southampton. Both missed, though HMS Southampton, assuming that the torpedo was fired by a U-boat, missed E6 when trying to ram it. ${ }^{27}$

In the fog, the German vessels withdrew, leaving three light cruisers and one destroyer sunk with 712 killed. ${ }^{28}$ No British vessel was sunk, and only 35 British seamen were killed. The Battle of the Bight was celebrated as a British victory, though it was clear to the British

\footnotetext{
20 Farquharson-Roberts (n19) 51.

21 Ibid.

22 Massie (n2) 104.

23 Wrecksite <http://www.wrecksite.eu/wreck.aspx?10826>.

24 Wrecksite <http://www.wrecksite.eu/wreck.aspx?10828>.

25 Massie (n2) 110.

26 Massie (n2) 114; Wolz (n15) 35.

27 Farquharson-Roberts (n19) 51.

28 Wolz (n15) 35; Farquharson-Roberts (n19) 52.
} 
Admiralty that it could easily have been a disaster, and that significant problems with British communication and strategy existed. ${ }^{29}$

\subsubsection{The Battles of Coronel and Falklands}

As part of its attempt to build a colonial empire, Germany had established its only overseas naval base in Tsingtao in China. When Japan joined the Allies, Tsingtao was blockaded and finally fell in November 1914. At the time, the German Far East Squadron, commanded by Vice-Admiral Graf Maximilian von Spee, had been at sea and as it could not return to Tsingtao, steamed towards Chile where it was able to obtain coal.

At the same time, concern that the commerce raider Dresden was significantly disrupting trade from the western coast of South America led the British Admiralty to create a South American Squadron under the command of Admiral Christopher Cradock, to deal with this threat. When von Spee's Far East Squadron was located off Chile, Cradock was sent complex and contradictory instructions that led him to engage von Spee with a substantially inferior force. During the engagement off Coronel the outdated and outgunned HMS Good Hope and HMS Monmouth were sunk. There were no survivors from either ship. This included Admiral Cradock together with 1,663 men. ${ }^{30}$ The modern light cruiser $H M S$ Glasgow was hit five times but escaped. In contrast, the Gneisenau was hit four times and the Schanrhorst only twice with no loss of life on either ship. ${ }^{31}$ Germany celebrated the Battle of Coronel as a resounding victory.

The British squadron regrouped in the Falkland Islands with additional modern vessels dispatched from duty in Europe. Von Spee, unaware of this, sailed to attack the Falklands, only to find a superior force gathered there. The aging pre-dreadnought battleship HMS Canopus, ordered to ground in Port Stanley harbour, opened fire first, alerting the German fleet to the larger British naval presence. In the following pursuit of the fleeing German fleet, the battlecruisers HMS Invincible and HMS Inflexible traded fire with the Schanrhorst and the Gneisenau. While the German gunnery was swifter and more accurate, the might of the British guns prevailed and the Scharnhorst was sunk with the loss of all 840 on

29 Massie (n2) 121.

30 Losses are listed as 925 of HMS Good Hope and 738 of HMS Monmouth. The Naval History Homepage <http://www.naval-history.net/xDKCas191411Nov2.htm>.

31 Farquharson-Roberts (n19) 58. 
board, including Admiral von Spee. ${ }^{32}$ The Gneisenau followed 90 minutes later. Of a compliment of 850 men, only 187 survived. ${ }^{33}$

The German colliers Baden and Santa Isabel had been pursued by HMS Bristol and HMS Macedonia and were caught, the crews taken off and then scuttled. ${ }^{34}$ The German light cruisers split up during the battle and were pursued by the British cruisers. HMS Glasgow and HMS Cornwall caught and sunk the Leipzig while HMS Kent sank the Nürnberg. The Dresden managed to escape and spent the following months hiding in the southern Chilean waters, breaching Chilean neutrality. When it was discovered by HMS Kent, and subsequently engaged by HMS Glasgow, again contrary to international law on Chilean neutrality, Dresden was damaged and then scuttled off Mas a Tierra. ${ }^{35}$

German losses during the Battle of the Falklands were significant. In addition to those lost on the Schanrhorst and Gneisenau, only 18 crew of a compliment of around 288 survived the sinking of the Leipzig and only seven from the Nürnberg's compliment of 322. ${ }^{36}$ Not only had Admiral von Spee been lost, but so too had his two sons; Heinrich on the Gneisenau and Otto on the Nürnberg. The battle of the Falklands was the first really devastating loss for the German navy, and yet the numbers lost still did not meet those already lost by the Royal Navy.

\subsubsection{Dogger Bank}

On 28 August 1914 at the entrance to the Gulf of Finland, the German cruiser Magdeburg ran aground and was scuttled when the Russian light cruisers Palladia and Bogatyr approached. After boarding the wreck, the Russians found a number of copies of the German navy codebook. ${ }^{37} \mathrm{~A}$ few weeks later, another codebook was recovered from the minelaying destroyer S119 which was sunk on 17 October 1914 off the Dutch coast. Shortly before it sank, its captain had dropped the codebook overboard in a lead-lined chest. Six weeks later, the chest was hauled up in a British fishing trawler's net and subsequently delivered to the Admiralty. ${ }^{38}$ These

\footnotetext{
32 Massie (n2) 271. Wrecksite <http://www.wrecksite.eu/wreck.aspx?15323>.

33 Wolz (n15) 46.

34 Faulkner (n5) 31. Wrecksite <https://www.wrecksite.eu/wreck.aspx?13 8097>.

35 Farquharson-Roberts (n19) 61; Ryan K Noppen German Commerce Raiders 1914-18 (Osprey Publishers, 215) 11-12.

36 Noppen (n35) 22; Wrecksite <http://www.wrecksite.eu/wreck.aspx?15322>.

37 Massie (n2) 315-16.

38 Massie (n2) 317.
} 
enabled the Admiralty to successfully break the German code. Such finds continued, and in 1916, further codebooks of both the Germany navy and the Austro-Hungarian navy were found by Italian navy divers on UC12, sunk by its own mine off Taranto. ${ }^{39}$

By early 1915, the German navy suspected that the British had some way of knowing the movement of the German fleet, and surmised that this information was being sent by the many fishing trawlers operating in the shallower waters of the Dogger Bank, situated in the middle of the North Sea approximately half way between Britain and Germany. Admiral Franz Hipper planned to sweep through the Dogger Bank clearing it of small craft and fishing vessels, and hoped to also draw out British cruisers that came to their defence. The German navy never suspected that their signals were being decoded, including those planning the sweep of the Dogger Bank, ${ }^{40}$ and when Hipper's fleet moved through the Dogger Bank, Rear-Admiral David Beatty's 1st and 2nd Battle Cruiser and 1st Light Cruiser squadrons engaged Hipper's fleet. ${ }^{41}$ Hipper quickly turned and fled towards Heligoland, with the faster British fleet moving on a parallel course in order to engage with broadsides of fire that were far superior in number and power to that of the German fleet. ${ }^{42}$ As the British fleet came into range of the German fleet, they began to fire on the last German vessel in the line of sail, Blücher. First HMS Lion, then HMS Tiger and HMS Princess Royal fired on Blücher from ranges that far exceeded anything that had occurred in any previous naval battle. ${ }^{43}$ As the British ships drew alongside the German line, they altered fire to engage the corresponding vessel in the line and the German fleet was able to exchange fire. Unfortunately, due to poor British communication, one German vessel, Moltke, was not engaged, allowed it to fire on HMS Lion, Admiral Beatty's flagship, without being fired on, scoring a number of hits on HMS Lion, which eventually had to drop out of the action due to damage sustained. A combination of poor communication and the damage to HMS Lion caused the British fleet to misunderstand Admiral Beatty's intentions and assumed that he had decided to disengage the fleeing German fleet and concentrate its attack of the flagging

39 P Enrico Cernuschi and Vincent P O'Hara 'Italy' in Vincent P O'Hara, W David Dickson and Richard Worth (eds) To Crown the Waves: The Great Navies of the First World War (Naval Institute Press, 2013) 186.

40 Massie (n2) 378.

41 Faulkner (n5) 46-7.

42 Massie (n2) 381.

43 Ibid. 388. 
Blücher. It was surrounded by the British fleet and ravaged, finally sinking, taking 966 of its crew of 1,200 with it. ${ }^{44}$

The remaining German fleet was able to make it back to Wilhelmshaven, though Seydlitz, Derfflinger and Kolberg were all very badly damaged. While this was certainly a British victory, the Admiralty viewed it as a qualified success, believing that the superiority of the British fleet meant that the German fleet ought to have all been sunk.

\subsubsection{The Dardanelles Campaign}

The Dardanelles, the Turkish strait linking the Sea of Marmara to the Aegean, and thus a waterway between the Black Sea and the Mediterranean, was the site of a significant British naval engagement and naval operation, though not against an opposing fleet, but rather against the shore defences of the Turkish army. Whilst best known for the subsequent land campaign, it and the earlier Dardanelles campaign had antecedents that arose from action initiated by the British Admiralty. At the very beginning of the war, the Royal Navy had attempted, and failed, to catch the Goeben and Breslau in the Mediterranean, allowing them to flee into the Black Sea. ${ }^{45}$ There they adopted Turkish nationality, though retaining their German crews, and subsequently bombarded Russian fortifications on the Black Sea coast, bringing Turkey into the war on the side of Germany. ${ }^{46}$ For a number of strategic reasons, including assisting its ally Russia, the First Lord of the Admiralty, Winston Churchill, devised a plan to open the Dardanelles strait, and defeat Turkey, through a naval action. ${ }^{47}$ By that time, the British Navy already had a sizable fleet stationed nearby to prevent the Goeben and Breslau entering the Mediterranean, and minor engagements had already occurred in the region. For example, in late 1914 the British submarine B11 sank the large, aging Turkish battleship Mesudiye with the loss of 38 of its 673 crew. ${ }^{48}$ The captain of B11, Lieutenant Norman Holbrook, was awarded the Victoria Cross, the first naval Victoria Cross of the war and the first for the

44 Ibid. 406.

45 Faulkner (n5) 8-9.

46 Farquharson-Roberts (n19) 77.

47 See Tom Curran The Grand Deception: Churchill and the Dardanelles (Big Sky Publishing, 2015).

48 Selçuk Kolay, Okan Taktak, Savaş Karakaş and Mithat Atabay Echoes from the Deep: Wrecks of the Dardanelles Campaign (2nd ed, Vehbi Koc and Ayhan Sahenk Foundations, 2015) 62-9; Wrecksite <http://www.wrecksite.eu/ wreck.aspx?99826>. 
submarine service. ${ }^{49}$ The British submarine E14 also had early success sinking the Turkish patrol ship Nur-ul Bahir in January 1915, for which its commander, Lieutenant Commander Edward Boyle was also awarded a Victoria Cross. ${ }^{50}$

Joined by a French contingent, the full naval operation began on 19 February 1915 with a bombardment of the Turkish forts that protected the opening of the straits. Accurate naval fire on land targets proved difficult and although the entrance forts were subdued, those further up the strait proved to be a significant challenge. Moreover, the extensive minefields in the straits could not be cleared by the converted minesweeping trawlers crewed mostly by civilian crew. On 18 March 1915, the British and French fleet attempted a renewed attack. The aging French battleship Bouvet was hit by a shell fired from Fort Hamidie, and at the same time hit a mine, ${ }^{51}$ sinking within a minute, taking 640 men with it, leaving only 66 survivors. ${ }^{52}$ Later HMS Inflexible and then HMS Irresistible also hit mines. While HMS Inflexible managed to withdraw, $H M S$ Irresistible was abandoned and subsequently sank. ${ }^{53}$ The crew of HMS Irresistible were rescued by HMS Wear, although 18 crew had been killed in the mine blast. ${ }^{54}$ Before it sank, consideration was being given to towing it using HMS Ocean, but it too hit a mine, and followed a similar fate, having been abandoned and later sinking. ${ }^{55}$ With these losses the naval assault was abandoned and the decision made to land troops on the Gallipoli peninsular.

The Gallipoli landings required considerable naval planning and naval deployment. On the first day of landing, 25 April 1915, a naval bombardment preceded the movement of troops, who were, for the most part, disembarked from the troopships about a mile from shore, towed further in by tug, and then left to row to the beach. ${ }^{56}$ The landing was fiercely resisted with the boats coming under howitzer and machine gun

49 Robert Hamilton Victoria Cross Heroes of World War One (Atlantic Publishing, 2015) 40.

50 Ibid 77.

51 Curran (n47) 111.

52 Massie (n2) 461. Kolay lists the losses as 603 lost and 36 survivors. See Selcuk Kolay and Savas Karakas 'Echoes from the Deep: Wrecks of the Dardanelles Campaign' in Guérin et al. (n12) 21.

53 Massie (n2) 462.

54 Wrecksite https://wrecksite.eu/wreck.aspx?99790 accessed 5 September 2018 lists 150 casualties. The Navy History Casualty List lists 13 dead $<$ http://www.naval-history.net/xDKCas1915-03Mar.htm>.

55 Massie (n2) 463.

56 Ibid. 478. 
fire, leaving wreckage, equipment and men littering the ocean floor. The only attempt to actually disembark troops directly ashore from a troopship was the beaching of the collier River Clyde with holes cut into its sides from which the troops would charge ashore. Unfortunately, the naval bombardment had not weakened the Turkish defences and River Clyde came under very heavy fire, with significant losses. For their role and heroism during this trying disembarkation, six sailors were awarded the Victoria Cross, including the commander, Captain Edward Unwin. ${ }^{57}$

The only naval activity was minor incursions, including action by the nascent Royal Australian Navy when its submarine AE2 navigated through the straits into the Sea of Marmara, but was damaged by a Turkish torpedo and subsequently scuttled, on the 30 April 1915, without any loss of life. ${ }^{58}$ Throughout the weeks following the landings, the significant naval presence stood offshore unchallenged. On 12 May, however, this peace was shattered when HMS Goliath was sunk by torpedoes fired from the Turkish destroyer Muavenet-i Milliye. HMS Goliath rolled over and sank very quickly with the death of 570 of its 750 crew. ${ }^{59}$ This was a celebrated achievement for the Turkish navy, though the Muavenet-i Milliye was commanded by a German officer. This was followed on the 25 May by the loss of the old battleship HMS Triumph, torpedoed by $U 21$ off ANZAC beach, taking 73 of its crew with it. ${ }^{60} \mathrm{U} 21$ followed this two days later by sinking the oldest battleship in the British navy, HMS Majestic, killing 40 of its 670 crew. ${ }^{61}$ On 4 July 1915, U21 sank the French liner Carthage near the entrance to the strait, with no casualties. ${ }^{62} U 21$ was not the only submarine operating in the area, and Britain also had some success with its submarines. E11 sunk the Turkish Barbaros Hayreddin on the 8 August 1915 and the Bosphorus on 4 December 1915, earning its commander, Lieutenant Martin Nasmith, the Victoria Cross; 63 the third awarded to a submarine commander in the campaign. Other losses followed, including by fire from

57 Hamilton (n49) 70.

$58 \quad$ Faulkner (n5) 81; Viduka (n12) 157.

59 Massie (n2) 483. Commander Henry Ritchie was awarded a Victoria Cross for earlier action aboard HMS Goliath. While the award was delayed and post-dated that of Lieutenant Holbrook, it was awarded for action that pre-dated those of Holbrook and thus is the first naval action for which a Victoria Cross was awarded. Hamilton (n49) 36.

60 Wrecksite <http://www.wrecksite.eu/wreck.aspx?454>.

61 Wrecksite <http://www.wrecksite.eu/wreck.aspx?430>. Massie (n2) 493.

62 Farquharson-Roberts (n19) 83.

63 Hamilton (n49) 81. Nasmith also became the Vice-Chairman of the Imperial War Graves Commission in 1945. 
the shore batteries including the French submarine Mariotte on 27 July $2015^{64}$ and the destroyer HMS Louis, on 30 October 2015.65

By December 1915, the decision had been taken to evacuate Gallipoli. The evacuation itself was an extraordinary success with only one casualty; a sailor who was hit by debris after an ammunition dump had been blown up using time-fused explosives. ${ }^{66}$ On land, the Gallipoli campaign had cost the lives of more than 50,000 allied troops. At sea, it had cost the Allied forces six large naval vessels, nine submarines ${ }^{67}$ and hundreds of sailors' lives. ${ }^{68}$ The Turkish navy too had suffered losses; two battleships, three destroyers, a torpedo boat and a gunboat. ${ }^{69}$ It also cost Winston Churchill his position as First Lord of the Admiralty, being replaced on 25 May 1915 by Arthur Balfour. ${ }^{70}$

\subsubsection{The Battle of Jutland}

Kaiser Wilhelm II was protective of his great battleships and did not wish to risk their loss in a pitched battle against the might of the British Grand Fleet. Rather, the German strategy was to wear down the British fleet, reducing its numbers to a point of parity with those of the German navy. When Vice-Admiral Reinhard Scheer became Commander-in-Chief of the German High Seas Fleet, he proposed doing so by luring a portion of the Grand Fleet, Admiral Beatty's Cruiser Fleet, out into a submarine trap. ${ }^{71}$ Since British Naval Intelligence was able to decode the German communication, Admiral Jellicoe quickly became aware of the German fleet movements and, welcoming the opportunity to meet the German High Seas Fleet, sent the Grand Fleet out. The two converging fleets were not equal. The German fleet consisted of 16 dreadnought battleships, six old pre-dreadnought battleships, five battlecruisers, 11 light cruisers and 62 destroyers, totalling exactly 100 ships. The British fleet on the other hand, consisted of 28 dreadnought battleships, nine battlecruisers, eight armoured cruisers, 26 light cruisers and 80 destroyers, totalling 151 ships.

\footnotetext{
64 Wrecksite <http://www.wrecksite.eu/wreck.aspx?174391>.

65 Faulkner (n5) 81.

66 Massie (n2) 501.

67 Including E15 on 15 April 1915 and E7 on 4 September 1915 both from shore battery fire. Faulkner (n5) 81.

68 Faulkner (n5) 81.

69 Ibid. 81

70 Curran (n47) 165.

71 Farquharson-Roberts (n19) 96.
} 
The first part of the battle of Jutland, known now as 'the run to the south' took place in the late afternoon of 31 May 1916. Admiral Beatty's Cruiser Fleet met the Scouting group of Admiral Hipper on a converging parallel course south. Inexplicably Admiral Beatty did not use his superior range and only started to fire once the British fleet was within the German fleet's range. The same poor communication that had occurred at the battle of Dogger Bank occurred again which meant that the British vessels did not fire on the corresponding German vessel in the fleet line, leaving Derfflinger to fire without being fired upon. German gunnery was superior and while the ships traded blows, the German guns were initially more effective. HMS Lion, Admiral Beatty's flagship, was hit when in the van of the fleet and might have suffered a fatal blow were it not for the courage and presence of mind of gunnery officer Major Francis Harvey. When the turret had been destroyed, killing most of the crew and mortally wounding Major Harvey, both of whose legs had been blown off, he ordered the closing of the magazine doors and the flooding of the magazine to prevent a backflash entering the explosive magazine. For this action, Major Harvey was awarded a posthumous Victoria Cross. ${ }^{72}$

Thereafter, HMS Indefatigable, already hit by 48 shells, was hit by two more from Van der Tam that penetrated the thin British armour causing a massive explosion that destroyed the ship and killing 1,017 of its crew. There were only two survivors. ${ }^{73}$ HMS Queen Mary, 20 minutes later, suffered the same fate with a similarly appalling loss of life; 1,266 of its crew perished, only two survived. ${ }^{74}$ Admiral Beatty then ordered his destroyers to attempt to torpedo the German battleships. Hipper countered with his destroyers and during the ensuing clash, the German destroyers V27 and V29 were sunk, as were the British destroyers HMS Nestor and HMS Nomad. For his actions during this destroyer engagement, the captain of HMS Nestor, Commander Edward Bingham was awarded the Victoria Cross. ${ }^{75}$ When the main German High Sea Fleet was seen to the south, Admiral Beatty turned his fleet and fled north, hoping that the German fleet would follow him to the waiting British Grand Fleet lying to the north. During the 'run to the north', both fleets exchanged fire.

The main fleet engagement of Jutland began around 6pm on 31 May 1915. In poor weather conditions, with considerable smoke from the

72 Massie (n2) 592; Hamilton (n49) 134.

73 Massie (n2) 593.

74 Farquharson-Roberts (n19) 106.

75 Ibid; Hamilton (n49) 135. 
coal-burning warships, it was difficult for the commanding officer on both sides to keep track of all their vessels and the multiple actions that took place. Admiral Jellicoe appeared to achieve the early advantage by bringing his Grand Fleet across the ' $\mathrm{T}$ ' of the German fleet so that each of his ships could fire on the leading German ship in turn. In the early engagements, the German light cruiser Wiesbaden was badly damaged, and recklessly pursued by Rear-Admiral Robert Arbuthnot and the four ships of his 1st Cruiser Squadron. Ignoring his position relative to the German Fleet, HMS Defence charged towards the stricken Wiesbaden, only to be blow apart by the large German guns, with the loss of all 903 men, including Admiral Arbuthnot. ${ }^{76}$ Shortly thereafter HMS Warrior was seriously damaged and disabled, and later sank. Later in the battle, $H M S$ Black Prince was also sunk with the loss of all of its 900 men. ${ }^{77}$ Only one of the vessels of the 1st Cruiser Squadron, HMS Duke of Edinburgh, returned to port after the battle. ${ }^{78}$

HMS Invincible had been firing very accurately and hitting Lützow and Derfflinger but had also been receiving shots. Then it was annihilated. Again, a British warship was sunk because the penetrating shell was allowed to ignite the cordite powder in the hoist, causing an explosion that travelled down the gun turret into the bowels of the ship, igniting the magazine and blowing the ship apart from the inside. Only six men survived this explosion; 1,031 of its crew perished. ${ }^{79}$ While three British battleships had sunk, the German battleships, though not sinking, were very badly damaged. The German warships had been designed to adhere to Admiral von Tirpitz's view that the first aim of a warship was to stay afloat. As such, they were not only covered with thick armour, but had effective watertight compartments.

Once under fire from Admiral Jellicoe's Grand Fleet, Admiral Scheer turned his fleet around, headed south, and then turned back again to face the British Grand fleet again. The German fleet was then engulfed in 'a solid, unbroken wave of endless thunder' ${ }^{80}$ With significant damage done to his fleet, Admiral Scheer again turned away from the Grand Fleet but sent his cruisers and destroyers to attack the fleet while the remainder of the German fleet made their escape. Then night fell, and the German destroyer fleet made use of its superior night equipment, especially their

\footnotetext{
76 Innes McCartney Jutland 1916: The Archaeology of a Naval Battlefield (Conway, 2016) 91.

77 Massie (n2) 647.

78 Ibid. 656.

79 Ibid. 618.

80 Ibid. 626.
} 
searchlights, and night fighting skills which the British had ignored. At the same time, Admiral Scheer used this opportunity to escape and slipped right through the British fleet. While a number of British vessels knew where the German fleet was, none informed Admiral Jellicoe, and no action was taken to prevent the German escape. During the night engagement, HMS Southampton, though hit a number of times with significant casualties, managed to torpedo the destroyer Frauenlob, which sank with the loss of its entire crew of $320 .{ }^{81}$ HMS Tipperary, a destroyer flotilla leader, also sank after suffering significant damage and being abandoned during the night, as did HMS Turbulent. In the frantic movement, accidents happened, and the German light cruiser Elbing was hit by the Posen and subsequently sank by scuttling. The British destroyers HMS Sparrowhawk and HMS Broke also collided and the former also subsequently sank.

As dawn arose, the German fleet suffered its largest casualty when the Pommern was torpedoed by HMS Faulkner, with the loss of its entire crew of $844 .{ }^{82}$ The Wiesbaden, which had been badly damaged and been a floating wreck for some time, also finally sank with only one survivor; while the Lützow, also slowly sinking, was scuttled by torpedo after its surviving crew had been taken off.

By the afternoon of 1 June 1916, the battle of Jutland was effectively over and the remaining fleets returned to port. In the largest sea battle of the war, the Royal Navy lost 14 ships totalling 115,025 tons while Germany lost 11 ships totalling 61,180 tons. Not only did the Royal Navy lose more ships of a far greater tonnage than the Germans, but the British loss of 6,094 naval personnel far exceeded the German loss of $2,551 .{ }^{83}$ The German fleet quickly claimed victory, based primarily on the number of ships sunk and the relative crew losses. The British Admiralty was much slower in reporting the battle and when it did, it merely reported the facts without any qualification or interpretation. From a British perspective, the German fleet had disengaged and fled the battlefield, leaving the British fleet in control of the seas. As such, Britain regarded the battle as a British victory. It was the last pitched sea battle of the war.

\footnotetext{
$81 \quad$ Ibid. 639.

82 Ibid. 648.

83 Faulkner (n5) 102.
} 


\subsection{THE WIDER NAVAL THEATRE}

While the war at sea was dominated by the British and German navies, the other belligerent navies too suffered losses. With Russia at war with Germany, the Baltic Sea became a naval theatre, though both nations took a defensive strategy to their naval operations. Both laid extensive minefields. Nevertheless, a few engagements and losses did occur. An important early loss for Germany was that of the light cruiser Magdeburg on 28 August 1914 at the entrance to the Gulf of Finland, from which the Russians obtained copies of the German navy codebook that became an important piece of the puzzle that allowed the British Admiralty to break the German naval code. ${ }^{84}$ Other German losses in the Baltic included the Undine on 7 November 1914, Friedrich Carl on 17 November 1914, Albatross on 2 July 1915, the T47 and T51 on the 29 May 1915 and the Prinz Adalbert on 23 October 1915.85 On 10-11 November 1916, the German fleet suffered a major loss when seven of the 11 destroyers of the $\mathrm{X}$ Destroyer Fleet were sunk by Russian mines when attempting to enter the Gulf of Finland. 86

The loss of the Magdeburg was avenged when U26 sank the Russian armoured cruiser Pallada on the other side of the Gulf of Finland entrance, with the loss of all 597 hands; Russia's greatest loss of the war. ${ }^{87}$ The other significant Russian loss occurred in the Black Sea when the dreadnaught Imperatristae Mariya sank off Sevastopol after exploding at anchor on 20 October 1916, with the loss of 228 of its crew. ${ }^{88}$ It is likely that this was caused by an accident rather than by sabotage, which was thought to be the cause at the time. ${ }^{89}$ The Russian navy also lost the Zhemchug off Thailand, sunk by the commerce raider Emden, with the loss of 89 of its 350 crew. ${ }^{90}$ While the Russian navy was engaged in both the Baltic and Black Seas, its role was minor compared to the other belligerent navies.

The Austria-Hungarian and Italian navies were also engaged in the war at sea, particularly in the Adriatic. A day after war was declared between Austria-Hungary and Italy, the Austro-Hungarian navy attacked Ancona

\footnotetext{
84 Faulkner (n5) 27; Massie (n2) 315-16.

85 Faulkner (n5) 26-7.

86 Stephen McLaughlin 'Russia' in O'Hara et al. (n39) 240.

87 Faulkner (n5) 26-7. Wrecksite <http://www.wrecksite.eu/wreck.aspx? 142338>.

88 Faulkner (n5) 119.

89 McLaughlin (n86) 253.

90 Faulkner (n5) 35. Wrecksite <http://www.wrecksite.eu/wreck.aspx?17528>.
} 
and a number of other Italian cities, in the process sinking the Italian destroyer Turbine. ${ }^{91}$ The first major loss for the Austro-Hungarian navy was that of the old cruiser Zenta on 16 August 1914 off the coast of Bosnia by French and British warships, with the loss of 179 of its 308 crew. ${ }^{92}$ In mid-1915, the Austro-Hungarian navy had lost a third of its destroyers. This included, for example, the Lika, after hitting a mine. ${ }^{93}$ This turned out to be an important loss as the Italian navy was able to obtain a full set of naval codes and handbooks from the wreck which assisted greatly in enabling the Italian navy to understand the structure of its Austro-Hungarian counterpart. ${ }^{94}$ Shortly thereafter, the AustroHungarian navy suffered its first loss of a submarine, U12, after hitting a mine on 8 August, followed by the loss of $U 3$ on 13 August 1915.95 The old battleship Wien was sunk in December 1917 by Italian torpedo motorboats with the loss of 46 of its 440 crew. ${ }^{96}$ In February the following year, the Szent István was also torpedoed with the loss of 89 of its 1,094 crew. $^{97}$ Coincidentally, the same Italian commander, Luigi Rizzo, sank both the Wien and Szent István.98

In its engagements, particularly in the Adriatic, the Italian navy also suffered a number of losses, the first of which was the destroyer Turbine with the loss of about 15 of its 53 crew. ${ }^{99}$ The Italian navy then lost the armoured cruiser Amalfi, sunk by the Austro-Hungarian U26 on 7 July 1915 with the loss of 150 of its 550 crew. In fact, $U 26$ was actually the German UB14, but since Italy was not at war with Germany until August 1916, it was marked as an Austro-Hungarian submarine. ${ }^{100}$ Later that month, the Italian navy also lost the old armoured cruiser Giuseppe Garibaldi sunk by the Austro-Hungarian U4 on 18 July 1915, with the

\section{Faulkner (n5) 62-3.}

92 Ibid. 28; Zvonimir Freivogel 'Austria-Hungary: Die Kaierliche und Königliche Kriegsmarine' in O'Hara et.al (n39) 41; Wrecksite <http://www. wrecksite.eu/wreck.aspx?148093>.

93 Zvonimir Freivogel ibid. 43. Wrecksite <https://www.wrecksite.eu/wreck. aspx?123269>.

94 Cernuschi (n39) 186.

95 Zvonimir Freivogel (n92) 43.

96 Wrecksite <http://www.wrecksite.eu/wreck.aspx?121715>; Zvonimir Freivogel (n92) 43-4.

97 Zvonimir Freivogel (n92) 44. Wrecksite <http://www.wrecksite.eu/wreck. aspx?131869>.

98 Zvonimir Freivogel (n92) 45.

99 Faulkner (n5) 62-3.

100 Wrecksite <http://www.wrecksite.eu/wreck.aspx?122001>. Zvonimir Freivogel (n92) 28. 
loss of 53 crew. ${ }^{101}$ A more significant loss followed on 11 December 1916 when the pre-dreadnought Regina Margherita sunk after hitting a mine with the loss of 684 crew. ${ }^{102}$ The destruction of the dreadnought Beneditto Brin in the harbour of Brindisi on 27 September 1915, thought to be the work of saboteurs, was also a great loss when 454 of its 841 crew perished. ${ }^{103}$ A similar fate awaited the dreadnought Leonardo da Vinci, sunk by internal explosion on 2 August 1916 with the loss of 248 of its crew. One of the last Italian vessels lost, the old cruiser Etruria, was also ostensibly an act of sabotage. It turned out, however that it had been deliberately sunk by the Italians in order to shore up its system of double agents and strengthen Austro-Hungarian confidence in their espionage network. ${ }^{104}$

The French navy, long the second most powerful, was surpassed by Germany by the time war began. ${ }^{105}$ It was, however, still a large global force given France's position as a colonial power, reflected in the sinking of the Mousquet by the Emden off Malaysia. ${ }^{106}$ The French navy played an important role in the Mediterranean and in the Dardanelles campaign. This led to some significant losses, beginning with the loss of the Bouvet with 640 of its 706 crew off Gallipoli on 18 March 1915. Shortly thereafter, on 27 April 1915, the armoured cruiser Léon Gambetta was sunk in the Mediterranean by the Austro-Hungarian U5, with the loss of 684 of its 821 crew. 107 The aging battleship Suffren, having suffered significant damage during the Dardanelles campaign, was sunk by U52 on 25 November 2016 with the loss of all 648 of its crew. The Gaulois, of the same class and age as the Suffen, was sunk shortly thereafter on 27 December 1916 by UB47, with the loss of only four of its crew. 108 The last large pre-dreadnought sunk was the Danton, torpedoed on 18 March 1917 by U64, with the loss of 296 of its 920 crew. ${ }^{109}$ A number of smaller French cruisers were also sunk, with great loss of life. The Amiral Charner, with a crew of 374, was torpedoed by $U 21$ in the

\footnotetext{
101 Wrecksite <http://www.wrecksite.eu/wreck.aspx?149157>.

102 Cernuschi (n39) 183.

103 Ibid. 187.

104 Ibid.

105 Jean Moulin 'France' in O'Hara et al. (n39) 54.

106 Moulin (n105) 78.

107 Zvonimir Freivogel (n92) 42. Wrecksite <http://www.wrecksite.eu/wreck. aspx?58597>.

108 Moulin (n105) 79. Wreck Site <http://www.wrecksite.eu/wreck.aspx? $58593>$.

109 Moulin ibid. Wreck Site <http://www.wrecksite.eu/wreck.aspx?130716>.
} 
Eastern Mediterranean on 8 February 1916, with only one survivor. ${ }^{110}$ Other important losses included the battlecruiser Kléber, mined on 27 June 1917 with the loss of 42 of its 531 crews; ${ }^{111}$ and the destroyer Dague, sunk on 24 February 1915 in the Adriatic with the loss of 38 of its 80 crew. ${ }^{112}$

The US only entered the war in 1917, prompted in part by the sinking of passenger liners by U-boats with the loss of American lives, as well as by the loss of American merchant vessels. ${ }^{113}$ America's war at sea was inextricably linked to the unrestricted U-boat campaign, and the first naval losses occurred on convoy duty in the Atlantic: the destroyers Chauncey on 20 November 1917 with the loss of 21 of its 91 crew and Jacob Jones on 6 December 1917 with the loss of 66 of its 99 crew. ${ }^{114}$ The U-boat campaign extended to the American shoreline in 1918, leaving a swath of sunken vessels along the American eastern seaboard. Between them, U117, U140 and U151 accounted for 53 merchant vessels. Also lost was the 11 year-old, obsolete USS San Diego. On 19 July 1918, it hit a mine laid off New York by U156, with the loss of six lives. ${ }^{115}$ On 6 August 1918, the Lightship LV71 was sunk and on the 26 September 1918, the Coast Guard Cutter Tampa was torpedoed by UB91 and lost with all of its crew of 115 as well as 16 passengers on board at the time. ${ }^{116}$

Japan did not have a significant role in the war at sea, but its one loss was significant. During the Siege of Tsingtao in October 1914, the Japanese light cruiser Takachiho was sunk by German torpedo boat $S 90$ with the loss of 271 of its crew. ${ }^{117}$ This was the largest single loss of Japanese servicemen during the war. ${ }^{118}$ It was also the first time that a warship of the Imperial Japanese Navy had been sunk by another

\footnotetext{
110 Moulin ibid. Wreck Site <http://www.wrecksite.eu/wreck.aspx?58595>.

111 Moulin ibid. Wreck Site <http://www.wrecksite.eu/wreck.aspx?5085>.

112 Wrecksite <http://www.wrecksite.eu/wreck.aspx?136994>.

113 James Delgado and Ole Varmer 'The Public Importance of World War I Shipwrecks: Why a State Should Care and the Challenges of Protection' in Guérin et al. (n12) 106.

114 Delgado and Varmer ibid. 107. Wrecksite <http://www.wrecksite.eu/ wreck.aspx?156710> and <http://www.wrecksite.eu/wreck.aspx?30970>.

115 Massie (n2) 761-2.

116 Wrecksite <http://www.wrecksite.eu/wreck.aspx?11272>.

117 Faulkner (n5) 29; Lawrence Sonderhaus The Great War at Sea (Cambridge University Press, 2014) 68.

118 Wrecksite <http://www.wrecksite.eu/wreck.aspx?37389>.
} 
vessel. ${ }^{119}$ The following day, $S 90$ ran aground off the Chinese coast and was subsequently abandoned. ${ }^{120}$

\subsection{THE SUBMARINE WAR}

At the beginning of the war, Britain had 73 submarines, more than any other navy. ${ }^{121}$ France had 50, though many were old and obsolete. ${ }^{122}$ None of the other belligerent navies had a large submarine fleet; Russia had 22, Italy had 20, US had 18, Japan had 12 and Austria-Hungary had only five. ${ }^{123}$ Germany had 31 but because Germany had been the last naval power to invest in submarines the German boats were newer and more advanced than any other fleet, especially the British which had a number of old boats in its fleet. ${ }^{124}$ The German Admiralty, like many of the other belligerent nations, had little faith in submarines and considered them only useful for defensive purposes, and therefore restricted them to patrolling the Heligoland Bight off Germany. They were also to be used, in the North Sea, for reconnaissance purposes rather than as an offensive weapon. ${ }^{125}$ Germany, however, more than any other nation, quickly appreciated the value of the submarine and its role in the war was to have significant ramifications.

The first engagement of the war involving a submarine resulted in the loss of the submarine rather than of a surface vessel. Sent to reconnoitre the British Grant fleet, U15 was rammed by the light cruiser HMS Birmingham on 9 August 2014, in the northern waters of the North Sea, roughly parallel with Scape Flow. U15 sank with all 23 crew. While this sinking delighted the British Admiralty, the fact that U15 was operating so far north, and so close to Scapa Flow, the base of the Grand Fleet, greatly concerned Admiral Jellicoe, who throughout the war would continue to fear a U-boat attack within the waters of Scapa Flow itself. ${ }^{126}$

On 5 September 1914, U21, captained by Otto Hersing, sank the first British warship, the light cruiser HMS Pathfinder. The single torpedo

\footnotetext{
119 Akifumi Iwabuchi, 'The Shipwreck of the Takachiho, Japanese Cruiser Sunk off China in 1914' in Guérin et al. (n12) 42.

120 Wrecksite <http://www.wrecksite.eu/wreck.aspx?157816>; Faulkner (n5)

121 Halpern (n9) 7-8.

122 Faulkner (n5) 3.

123 Cernuschi (n39) 184.

124 See U-boat net <http://uboat.net/wwi/boats/listing.html>.

125 Massie (n2) 127.

126 Ibid. 79.
} 29. 
fired by $U 21$ hit the forward magazine of HMS Pathfinder, sinking it within four minutes with the loss of at least half of its crew of $360 .{ }^{127} \mathrm{~A}$ little over a week later, on 13 September, the British submarine E9, commanded by Lieutenant Max Horton, sank the first German vessel of the war, the light cruiser Hela. ${ }^{128}$ Only two of its crew were lost despite the Hela sinking very quickly. ${ }^{129}$ Three weeks later E9 also sank the German destroyer S126.130 The first allied submarine lost was the Australian AE1, missing on patrol off New Britain (Papua New Guinea) on 14 September 1914 with the loss of all 35 crew. ${ }^{131}$

The risk posed by U-boats, particularly to the slower older predreadnought battleships, was amply illustrated early in the war at sea. At the beginning of hostilities, the elderly Bacchantes class cruisers, laid down in 1898 and 1899, had been due to be scrapped, but were retained to patrol the Broad Fourteens off the Dutch coast. Given their age, and the inexperience of their reservist crews, they were referred to in the fleet as the 'live bait squadron'. ${ }^{132}$ This proved prophetic. On 22 September 2014, U9 torpedoed HMS Aboukir. Its captain thought he had hit a mine, and shortly before it sank and then capsized, signalled the HMS Cressy and HMS Hogue to assist in picking up survivors. The captain of the HMS Hogue however realised that a submarine had caused the sinking, but nevertheless attempted to pick up survivors. It too was struck by two torpedoes fired from $U 9$, and sank in ten minutes. Shortly thereafter $H M S$ Cressy also stopped to pick up survivors, was struck by two torpedoes from $U 9$, rolled over, and 20 minutes later, sank. ${ }^{133}$ Two Dutch steamships, Flora and Titan, and a number of Dutch trawlers came to pick up survivors, but a total of 62 officers and 1,397 men of these three warships drowned. ${ }^{134}$ The loss was a profound shock to the Royal Navy, not just in terms of the loss of seamen, but in the appreciation of the threat of U-boats. The action was celebrated as a significant victory in Germany. U9's captain, Otto Weddigen, was awarded the Iron Cross, First class,

\footnotetext{
127 Ibid. 128; Wrecksite <http://www.wrecksite.eu/wreck.aspx?435>.

128 Ibid. 125.

129 Wrecksite <https://www.wrecksite.eu/wreck.aspx?10830>.

130 Massie (n2) 125.

131 Amelia McMahon 'Naval Mystery Solved with Discovery of HMAS AE1' Defence Connect 21 December $2017<$ https://www.defenceconnect.com.au/ maritime-antisub/1714-naval-mystery-solved-with-discovery-of-hmas-ae1>.

132 Massie (n2) 129.

133 Faulkner (n5) 23.

134 Massie (n2) 136. See Robert Anthony York, 'World War I Underwater Cultural Heritage and the Loss of the HMS Aboukir, HMS Cressy and HMS Hogue 1914' in Guérin et al. (n12) 86.
} 
and every member of the crew the Iron Cross, Second Class. U9 continued its success during the next tour of duty the following month, sinking the outdated armoured cruiser HMS Hawke on 15 October 1914, with the loss of over 500 of its crew. ${ }^{135}$ Other early U-boat success included the sinking of HMS Hermes by U27 on 31 October 1914, with the loss of 22 crew $^{136}$ and HMS Formidable by U24 on 1 January 1915, with the loss of 563 men. ${ }^{137}$ These successes, especially that of $U 9$, were a revelation to both sides. ${ }^{138}$

A key British strategy in the war was the blockade of Germany. Whilst the Hague Convention of 1907 and the unratified 1908 Declaration of London had attempted to regulate the international law applicable to blockades and, importantly, the right of neutral shipping, there was much disagreement on these laws and their interpretation, including what material amounted to contraband, and when neutral vessels and their cargo could be seized. This led to significant disagreement with the US in relation to US vessels trading with Germany and other European nations, many of which were being used as entry points that ultimately led to Germany. German naval attempts to break this blockade had not been particularly successful, and it was to the U-boat that the German Admiralty turned. ${ }^{139}$

When Britain declared the entire North Sea a war zone, Germany began to consider the use of U-Boats to attack British commerce. ${ }^{140}$ In accordance with international law, and article 112 of the German Naval Prize Regulations, restricted U-boat warfare would require the U-boat to surface, halt the merchant vessel to establish its nationality, and if an enemy, would have to make provision of the safety of its crew or passengers before sinking the vessel. ${ }^{141}$ However, it would be impossible

135 Anthony Firth, 'The East Coast War Channels in the First World War' in Guérin et.al (n12) 145; U-boat net <http://uboat.net/wwi/boats/index.html? boat $=9>$.

136 Wrecksite <http://www.wrecksite.eu/wreck.aspx?19>.

137 Faulkner (n5) 12, 44; Wrecksite <http://www.wrecksite.eu/wreck.aspx ?405>.

138 Augusto Salgado and Jorge Russo 'The History and Underwater Archaeology of World War I: The Case of the Operations of U-35 off the Coast of Algarve, Portugal' in Guérin et al. (n12) 25.

139 Massie (n2) 503-14.

140 Early U-boat attacks on merchant shipping, according to German Prize Regulations, included the Glitra by U17 in October 1914, the French steamer Amiral Ganteaume by $U 24$ also in October 194; and the Malachite and Primo by U21 in November 1914. Massie (n2) 523.

141 Ibid. 515. 
to take the crew or passengers on board a U-boat, and during this process, the U-boat would be at its most vulnerable. Unrestricted U-boat warfare did away with these niceties, and allowed U-boats to sink indiscriminately. For some time, the German navy vacillated between the extremes of unrestricted U-boat warfare and some form of restricted warfare. On 4 February 1915, Germany declared the waters surrounding Britain a war zone in which all enemy merchant shipping would be sunk, and while neutral ships were to be avoided, the danger faced by the difficulties in identifying ships meant that they might be sunk. ${ }^{142}$ The US reacted to this by declaring that the loss of any US vessel or US citizens, including those travelling on a vessel flying the flag of a belligerent nation, would be an indefensible violation of neutral rights. ${ }^{143}$

The increased U-boat activity led to more, but not substantial, merchant shipping losses. It also led to increased U-boat losses. In the first 28 months of the war, 49 U-boats were destroyed. Early losses included U8 sunk by the destroyer HMS Ghurka off Dover, ${ }^{144}$ U12 rammed and sunk by the destroyer HMS Ariel off the coast of Scotland, ${ }^{145}$ and U29, rammed and sunk by HMS Dreadnought off Scapa Flow. ${ }^{146}$

The sinking of the British passenger liners Falaba, and Lusitania with the loss of American civilian lives, risked bringing America into the war, and led to a cessation of U-boat attacks on merchant shipping.

Following the battle of Jutland, the German navy saw no prospect of advancing the war at sea using its battleships. With the war in Europe going badly, the blockade of Germany proving effective and the risk of America entering the war, the Germany navy convinced the German command that unrestricted submarine warfare would effectively blockade Britain and with huge merchant shipping losses and the fall of important war material, Britain would be forced to come to terms. On 31 January 1917, unrestricted submarine warfare commenced. ${ }^{147}$ This change in

142 Ibid. 518-19.

143 Ibid. 522.

144 The crew of $U 8$ appear to have all survived as it surfaced before being sunk. U-boat net <http://uboat.net/wwi/boats/index.html?boat=29>. HMS Ghurka was later sunk after hitting a mine with the loss of 74 of its 79 crew. Wrecksite $<$ http://www.wrecksite.eu/wreck.aspx?107>.

14520 of the crew of $U 12$ died; ten survived. U-boat net <http://uboat.net/ wwi/boats/index.html?boat $=12>$.

146 All 31 crew of U29, including Captain Otto Weddingen, who had captained U9 when it sank the HMS Aboukir, HMS Cressy and HMS Hogue, died. U-boat net <http://uboat.net/wwi/boats/index.html?boat=29>.

147 See Faulkner (n5) 60-61 for a geographical account of the U-boat campaign. 
strategy led to an exponential increase in U-boat construction, unprecedented loss of shipping tonnage and significant merchant crew and civilian deaths at sea. This strategy was to have significant consequences for Germany. On the 6 April 1917, the US entered the war against Germany.

With mounting merchant shipping losses, the British Admiralty began to concentrate on the means to defeat the U-boats. U-boat technology had improved dramatically, the new boats carried 16 torpedoes as well as a 4.1-inch deck gun and could remain at sea for up to six weeks. ${ }^{148}$ Defeating these boats required a number of different approaches. One of the successful changes in strategy was the introduction of the convoy system, allowing merchant vessels to travel together with a number of destroyers. While this did not lead to the destruction of U-boats, what it did do, and which was more important, was to drastically reduce the amount of merchant shipping losses; allowing Britain to continue to prosecute the war. In the last 12 months of the war, 92 per cent of Allied merchant shipping sailed in convoy with a loss rate of less than 0.5 per cent. ${ }^{149}$ Moreover, in May 1917, the first US warships entered British waters. This deployment increased incrementally so that there were 37 US destroyers by July 1917 and by the war's end, there were 79. Only one, the USS Jacob Jones, was lost; torpedoed by U53.150 To counter the U-boat threat, extensive minefields were laid. Anti-submarine nets were also laid, which were attached to mines and proved effective particularly in the English Channel. The effort to destroy the U-boat offensive included raids on the U-boat bases in Zeebrugge and Ostend in 1918. This strategy included sinking a number of obsolete and heavily ballasted warships as blockships inside or just in front of the harbours. ${ }^{151}$

The last U-boat to be sunk during action was also one of only two to be sunk in the same way. ${ }^{152}$ On 28 October 1918, in the last action by the German navy, UB116 attempted to enter Scapa Flow. Hoxa Sound, through which UB116 attempted to enter, was defended by hydrophones that could amplify the sound of an entering vessel and by undersea cables

\footnotetext{
148 Massie (n2) 716.

149 Ibid. 738.

150 Ibid. 736.

151 Blockships were used in a number of ports. HMS Hood is a particularly well-preserved example of a blockship in the entrance of Portland Harbour, Dorset. Serena Cant and Mark Dunkley 'The Naval War' in Wayne Cocroft and Paul Stamper (eds) Legacies of the First World War (Historic England, 2018) 38. 152 The other is UB109. See Innes McCartney The Maritime Archaeology of a Modern Conflict (Routledge, 2015) 62.
} 
that could pick up the magnetic current of a vessel. A minefield was also laid that was connected to shore and could be set off electronically. When UB116 was picked up, and then subsequently came up to periscope depth, the mines were set off electronically from shore, sinking the U-boat with the loss of all its 35 crew. ${ }^{153}$ The last British warship sunk by a U-boat was HMS Britannia, torpedoed on 9 November 1918, fortunately with no loss of life. ${ }^{154}$

During the 51 months of the war, U-boats had sunk a total of 5,282 Allied and neutral ships totalling 11,153,000 tons. The most common cause of loss of both warships and Auxiliary vessels, at least for the Royal Navy, was by submarines, and most commonly by being torpedoed by the submarine. ${ }^{155}$ In comparison with this U-boat activity, the use of submarines by the Royal Navy was much more limited, used mainly against German warships and Auxiliary vessels rather than merchant vessels. The use of submarines by the other belligerent States was a great deal more limited than that of the principle antagonists at sea. Italy only had limited success with its submarines ${ }^{156}$ as did France. ${ }^{157}$ AustroHungarian submarines had more success, managing to sink 137 merchant vessels totalling 196,093 gross tons; a fraction of that sunk by German U-boats. ${ }^{158}$ In the Adriatic, for example, only 11 vessels were sunk by the combined submarines of Italy, France and Britain. ${ }^{159}$

This increased submarine activity, particularly for Germany, came with a heavy toll on lives, given the likelihood that the submarine could be lost with all hands. With the increased submarine menace, anti-submarine measures were developed. Mines in particular were quickly improved, especially by the Royal Navy and the depth charge invented. A barrel loaded with 300 pounds of TNT, triggered by a pressure fuse set to a specific depth, the depth charge become an effective anti-submarine weapon. On 13 December 1916, the first U-boat, UB29, was sunk by a

153 Massie (n2) 161.

154 Ibid. 763.

155 For example, of the 254 Royal Navy warships lost during the war at sea, 62 were by submarines, while 289 of the 815 lost Auxiliary vessels were by enemy submarines. British Vessels Lost at Sea 1914-1918: A reprint of the original official publications Navy Losses and Merchant Shipping (Losses) which were first published in August 1919 by His Majesty's Stationary Office London (Patrick Stevens, 1977) 8 and 29.

156 Cernuschi (n39) 195.

157 Moulin (n105) 81.

158 Zvonimir Freivogel (n92) 47.

159 Cernuschi (n39) 200. 
depth charge, with the loss of all 22 crew. ${ }^{160}$ The Italian navy experimented with towed torpedoes, but had only one success, sinking the Austro-Hungarian U23 in early 1918. ${ }^{161}$ Italy's other unusual antisubmarine tactic was the construction, with support from France, of a fixed mined boom that stretched from Brindisi to Corfu; $66 \mathrm{~km}$ long, $50 \mathrm{~m}$ high and hanging $10 \mathrm{~m}$ deep. While it may have been a deterrent, it caused only one confirmed loss, that of UB53 in August 1918, with the loss of ten of its 36 crew. ${ }^{162}$

Ramming also accounted for a number of submarines. The French submarine Monge, for example, was rammed by the Austro-Hungarian cruiser Helgoland in December 2015 with the loss of three crew. ${ }^{163}$ On 12 May 1918, the converted liner Olympic, while carrying troops back to America, rammed U103, cutting it in half, killing ten of its crew. ${ }^{164}$ This was the only submarine lost to a troop carrier. Some submarines were lost in unique circumstances. The French Foucault, for example, was the only submarine whose sinking was related directly to damage suffered from being bombed by aircraft, in this case the Austro-Hungarian aircraft L132 and L135 on 15 September 1916. ${ }^{165}$ Similarly, UB115 was sunk after initially being bombed by the British airship $R 29$, although finished off by being depth charged by a number of other vessels, guided to the target by the airship. ${ }^{166}$

The British Admiralty also resorted to the use of disguised armed merchant vessels, or Q-ships, to draw in and then sink U-boats. Despite their notoriety, Q-ships sank only 12 U-boats. ${ }^{167}$ It did, however produce the most decorated naval officer of the War, Commander Gordon Campbell, who was awarded, among others, the Distinguished Service

160 Massie (n2) 523, 736. Wrecksite <http://www.wrecksite.eu/wreck.aspx ?73463>.

161 Cernuschi (n39) 200.

162 Ibid. 211. U-boat net <http://uboat.net/wwi/boats/index.html?boat=UB+ 53>. Wrecksite <http://www.wrecksite.eu/wreck.aspx?175947>. See also Zvonimir Freivogel (n92) 44 suggesting that $U 6$ and possibly UB44 were also lost in this way.

163 Zvonimir Freivogel (n92) 34.

164 Massie (n2) 763. U-boat net <http://uboat.net/wwi/boats/index.html? boat $=103>$.

165 Zvonimir Freivogel (n92) 35; Wrecksite <http://www.wrecksite.eu/wreck. aspx?237105>.

166 Serena Cant England's Shipwreck Heritage: From Logboats to U-boats (English Heritage, 2013) 111.

167 Massie (n2) 722. 
Order and bar as well as the Victoria Cross. ${ }^{168}$ It also produced a posthumous Victoria Cross for Lieutenant William Sanders, who was lost with the entire crew of the Q-ship Prize, destroyed in a duel with UB48. ${ }^{169}$

Submarines were also sunk by other submarines. The first engagement between opposing submarines occurred early in the war when $D 8$ saw $U 28$ on the surface and fired a torpedo at it. $U 28$ saw the oncoming torpedo and dived. The two submarines subsequently spent the next hour and a quarter rising, diving, trying and failing to get the advantage, and finally $U 28$ retired. ${ }^{170}$ On 18 October, however, E3 was 'stalked, torpedoed and sunk' by $U 27$, with the loss of all 28 crew. ${ }^{171}$ This was the first successful sinking of one submarine by another. Others followed. U6 was torpedoed by E16 off the coast of Norway with the loss of 24 of its 29 crew. ${ }^{172}$ UC65 was sunk by C15 in the English Channel, ${ }^{173}$ as was $U B 72$, sunk by $D 4 .{ }^{174}$ The French Ariane was torpedoed by $U 22$ with the loss of all but eight of its 29 crew; 175 and the Italian submarine Medusa was sunk by $U 11$ near Venice on 10 June 1915 with the loss of 14 of its 21 crew. ${ }^{176}$ So too was the Italian submarine Nereide sunk on 5 August 1915 by $U 5^{177}$ with the loss of all 19 of its crew, including its Captain, Carlo del Greco, who was posthumously awarded the Medaglia d'Oro al Valore Militare. ${ }^{178}$

Not surprisingly, many submarines simply went missing, particularly those of Germany. One of the earliest was $U 13$, which simply failed to return to port, the conclusion drawn that it had probably hit a German mine in one of the minefields laid in the Heligoland Bight. ${ }^{179}$ Similarly, the Australian submarine $A E 1$ vanished without trace off New Britain (now Papua New Guinea) in September 1914 with all 35 crew. ${ }^{180}$ A

168 Ibid. 725. Hamilton (n49) 192.

169 Hamilton (n49) 215. Q-ship action also saw Victoria Crosses awarded to Ernest Pitcher and Charles Bonner on HMS Dunraven and Harold Auten on HMS Stockforce. See Cant and Dunkley (n151) 44.

170 Massie (n2) 126.

171 Ibid.

172 U-boat net <http://uboat.net/wwi/boats/index.html?boat=6>.

173 With the loss of 23 crew; five survived. McCartney (n153) 93.

174 With the loss of 32 crew; three survived. Ibid. 100.

175 Moulin (n105) 80; Wrecksite <http://www.wrecksite.eu/wreck.aspx? 144851>.

176 Zvonimir Freivogel (n92) 43.

177 Ibid. 43, 54.

178 Wrecksite <http://www.wrecksite.eu/wreck.aspx?146177>.

179 Massie (n2) 127.

180 Wrecksite <http://www.wrecksite.eu/wreck.aspx?138019>. McMahon (n131). 
number of British submarines also simply disappeared with all hands, including C31 (16 crew), C33 (16 crew), and D2 (25 crew). Submarines also foundered in unusual circumstances. The minelaying $U C 2$, for example, sank after hitting one of its own mines. ${ }^{181}$

By the end of the war, the extensive use of U-boats by Germany came at a heavy toll. 178 U-boats, almost 50 per cent of the fleet, had been lost in action with the loss of 511 officers and 4,575 men. ${ }^{182}$ While the submarine service of Germany lost more boats and men than any other, all the belligerent nations lost submarines, on many occasions, with all crew. Britain lost 52 submarines together with two of the Royal Australian navy. France lost 14 submarines during the war. ${ }^{183}$ The losses included the Joule with all $31 \mathrm{crew}$ on 1 May 1915 after hitting a mine;184 the Bernoulli with all 23 crew on 12 February 1918 after hitting a mine; 185 and the Ariane, torpedoed by $U 22$ with the loss of all but eight of its 29 crew. ${ }^{186}$ The Italian navy only lost eight submarines during the war. ${ }^{187}$

\subsection{MINES}

Warships were lost individually to a number of causes. One of the most common was to mines. ${ }^{188}$ Because mines are indiscriminate and sink any vessel, their use was regulated by the Hague Convention 1907. In particular, to keep the high seas free of this menace, offensive mine laying was supposed to take place only in the territorial waters of the belligerent States, that is within $3 \mathrm{~nm}$ of the coast. However, because the North Sea was so shallow and suitable for moored contact mines, Germany started laying mines on the very first day of the war in contravention of the Hague Convention, eventually laying over 250,000 mines. ${ }^{189}$ Mines were also laid on the western side of the British Isles, and it was here that one of the earliest, and most significant, loss

181 Gino Decuninck et.al 'World War I Underwater Cultural Heritage in the Belgian Part of the North Sea: A Preliminary Overview' in Guérin et al. (n12) 66. 182 Massie (n2) 780.

183 Moulin (n105) 61

184 Ibid 80; Wrecksite <http://www.wrecksite.eu/wreck.aspx?148364>.

185 Ibid.; Wrecksite <http://www.wrecksite.eu/wreck.aspx?237109>.

186 Ibid; Wrecksite <http://www.wrecksite.eu/wreck.aspx?144851>.

187 Cernuschi (n39) 184.

188 For example, of the 254 Royal Navy warships lost during the war at sea, 44 were due to mines, while 225 of the 815 lost Auxiliary vessels were due to mines. British Vessels Lost at Sea 1914-1918 (n156) 8 and 29.

189 Massie (n2) 140. 
occurred. HMS Audacious, a new King George V-class battleship launched in 1912, sank off the coast of Northern Ireland on 27 October 1914 having struck a mine laid by Berlin in the previous week. While there was only one casualty, the loss of what was one of the Royal Navy's most modern battleships was a cause of great concern, and its sinking was kept a secret for as long as possible. ${ }^{190}$

The British Navy had, at the outbreak of the war, little in the way of mine-laying technology, and as little in the way of anti-mine technology. Initially, lacking any minesweepers, the strategy was to sink the German mine-laying vessels. Success in this was, however, rare; though an early success was the sinking of four German mine-laying destroyers, S115, S117, S118 and S119 by HMS Undaunted and four accompanying destroyers in October 1914. ${ }^{191}$

The Russian navy was also a keen proponent of mine warfare and laid extensive minefields of around 35,000 mines in the Baltic, with its most notable success the virtual destruction of the German X Destroyer Fleet. ${ }^{192}$ The French navy too had no real mine-warfare strategy and laid only about 4,700 throughout the war. ${ }^{193}$ The Adriatic too was shallow and conducive to the laying of minefields. Between 1915 and 918, the Italian navy laid 12,293 mines while German minelaying submarines laid 565 along the Italian coast. ${ }^{194}$ Austria-Hungary too laid mines, including 1,500 off Pola alone. ${ }^{195}$

\subsection{COMMERCE RAIDERS}

A particular feature of the war at sea was the German strategy of commerce raiding. The British Empire, unlike that of Germany, had extensive colonies that fed the British economy and the German strategy of commerce raiding was to interfere and attack this commercial traffic. Commerce raiding had not been a primary strategy at the beginning of the war but quickly developed into an effective strategy given the distribution of German vessels around the world. While not extensive, these vessels were strategically placed, and Germany's few overseas colonies had been chosen primarily for their use as coaling stations for

\footnotetext{
190 Ibid 141-2.

191 Ibid. 140.

192 McLaughlin (n86) 248.

193 Moulin (n105) 74.

194 Cernuschi (n39) 201.

195 Zvonimir Freivogel (n92) 35.
} 
the fleet. ${ }^{196}$ A number of cruisers were built specifically to be used together with the battlefleet, as well as on overseas duties including commerce raiding. These included the cruisers Dresden, Königsberg, Emden, Karlsruhe and Leipzig, all of which were eventually sunk. ${ }^{197}$

The most successful commerce raider was the Emden. ${ }^{198}$ During its relatively short raiding career, it sank 78,742 tons of merchant shipping, bombarded the port of Madras in India, sank the Russian cruiser Zhemchug and the French destroyer Mousquet off Malaysia and, at one point, had 16 warships searching for it. ${ }^{199}$ It was eventually tracked down by the light cruiser HMAS Sydney, and after having all its guns knocked out and 134 of its 314 crew killed, Emden was beached on North Keeling Island, Australia. ${ }^{200}$

The Königsberg ${ }^{201}$ was the German navy's only presence in the Indian Ocean at the outbreak of war, and was used to attack allied shipping approaching the Red Sea or attempting to approach Suez. Its only success as a commerce raider was the sinking of the City of Winchester on the 13 August 1914 off today's Yemen. When pursued by British cruisers from the Cape Station to the Rufiji Delta of German East Africa (Tanzania), it managed to damage HMS Pegasus, killing 38 of its crew, which sank later that day.202 The Königsberg was found by $H M S$ Dartmouth, and prevented from leaving until HMS Severn and HMS Mersey arrived from Malta. Using an aircraft as a spotter, they were able to fire on the Königsberg and finally sink it in the delta. ${ }^{203}$

The Karlsruhe, operating in the Caribbean and southern Atlantic off Brazil, was relatively successful as a commerce raider. ${ }^{204}$ On 4 November 1914, a massive explosion tore the bow off the ship, killing its captain and 262 of its 385 crew, and sinking it. The cause still remains a mystery. It had, during its career, sunk 16 merchant ships totalling 72,800 tons. ${ }^{205}$

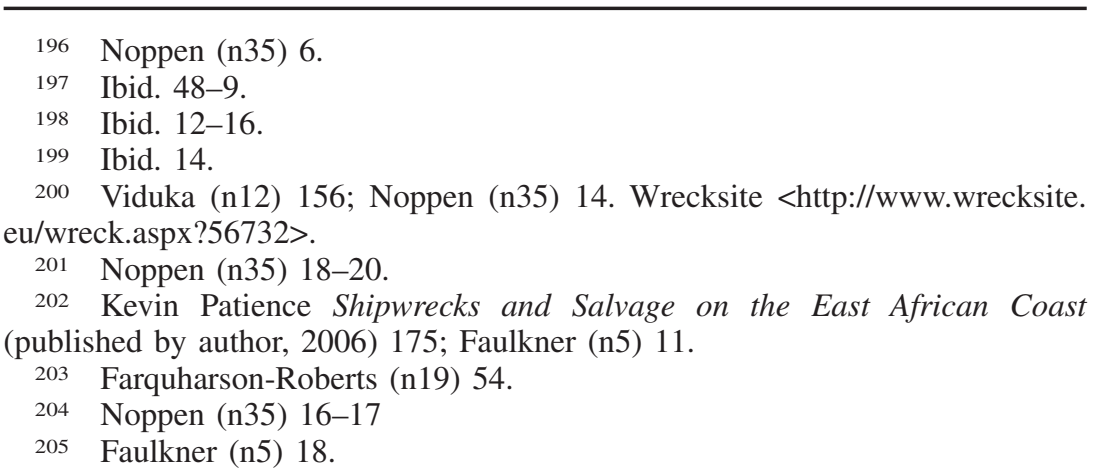


The Leipzig had a short raiding career before being attached to Admiral von Spee's squadron and sinking at the battle of the Falklands. ${ }^{206}$ Dresden had a similarly short raiding career and too was attached to Admiral von Spee's squadron, though it managed to escape, only to be sunk later off the coast of Chile. ${ }^{207}$

Commerce raiders were not, however, necessarily warships. Early in the development of the Imperial navy, arrangements had been put in place with a number of German shipping lines, particularly Hamburg America and Norddeutscher Lloyd, for liners to be built so that they could be used as armed vessels in war. ${ }^{208}$ Similar arrangements had been made in Britain with lines such as Cunard. ${ }^{209}$ At the outbreak of war, both Britain and Germany requisitioned and armed a number of liners, particularly the large transatlantic liners. The German Imperial navy used a number specifically as commerce raiders.

The liner Cap Trafalgar was a designated auxiliary cruiser when war broke out and was quickly mobilised. Once armed, it headed for the sea-lanes off South America where it encountered HMS Carmania, a Cunard liner requisitioned and armed as a British armed auxiliary cruiser. The two vessels exchanged fire. The Cap Trafalgar's fire was more accurate but the HMS Carmania was more heavily armed and inflicted the greatest damage, eventually sinking the Cap Trafalgar. HMS Carmania, however, had been so badly damaged in the encounter that the British Admiralty concluded that requisitioned liners could not feasibly be used as armed cruisers and they were thereafter used solely as troop ships. The Cap Trafalgar had the shortest career as a commerce raider and sank no merchant vessels, yet its place in history is secured, as this was the only clash to take place between armed auxiliary liners of the war. ${ }^{210}$

One of the first vessels captured by the Emden was the Russian Ryazan, which was converted into an armed auxiliary cruiser and renamed the Comoran.211 Designated to raid the shipping lanes off Australia, it had no success and was plagued with mechanical problems. It was eventually interred in Guam, and when the US entered the war, was scuttled by its captain, although nine crew died in the event and were

\footnotetext{
206 Noppen (n35) 21-2.

207 Ibid. 11-12.

208 Ibid. 5.

209 Ibid. 26.

210 Ibid. 36.

211 Ibid. 26.
} 
buried on the island. ${ }^{212}$ The Captain and remaining crew then became the first German prisoners-of-war taken by the US. ${ }^{213}$

The Kaiser Wilhelm der Grosse, a Norddeutscher Lloyd designated auxiliary cruiser, was dispatched to the Atlantic for commerce raiding and had very modest success. ${ }^{214}$ Found in the Spanish port of Rio de Oro in North Africa (now Morocco) by the cruiser HMS Highflyer on 16 August 2014, it eventually came out to engage and was hit a number of times and, out of ammunition, was scuttled off the coast. ${ }^{215}$ Another Norddeutscher Lloyd liner Kronprinz Wilhelm had somewhat more success than the Kaiser Wilhelm der Grosse, but by March 1915 was so unseaworthy and short of coal and provisions that it sailed into Chesapeake Bay and US internment. ${ }^{216}$ The Prinz Eitel Friedrich had a similar fate. ${ }^{217}$

The Berlin, a Norddeutscher Lloyd liner was unique in that it was not designed to be converted as an armoured cruiser, but was nevertheless requisitioned and outfitted to lay mines. In October 1914, it laid a minefield off Northern Ireland, which eventually claimed the battleship HMS Audacious. It was interred in Norway later in the year. ${ }^{218}$

Within a year, all the auxiliary liners had either been sunk or interred. The German navy then turned to converting freighters into auxiliary cruisers and minelayers, with greater success, beginning with the Meteor. A converted British freighter (the Vienna), the renamed Meteor successfully broke through the British blockade, laid a number of minefields, captured three merchant ships and sank another before being scuttled to avoid capture. ${ }^{219}$ The Möwe 220 and Wolf221 followed and were even more successful in terms of tonnage sunk. Neither was sunk, both returning to Kiel after the vessels became unseaworthy. The most unusual commerce raider was the Seedler, ${ }^{22}$ a captured American three-masted windjammer. Disguised as a Norwegian windjammer, the Seedler took a

\footnotetext{
212 Delgado and Varmer (n113) 108.

213 Noppen (n35) 28.

214 Ibid. 29.

215 Ibid. 30.

216 Ibid. 32.

217 Faulkner (n5) 48-9; Ibid. 33-4.

218 Ibid. 24-5.

219 Ibid. 35.

220 Faulkner (n5) 114; Ibid. 37-8.

221 Faulkner (n5) 120; Ibid. 39-43.

222 Ibid. 118.
} 
number of prize merchant vessels before being wrecked on the Mopelia atoll in what is today French Polynesia. ${ }^{223}$

The German commerce raiders sank 162 vessels totalling 661,915 tons. $^{224}$ While this was only a fraction of that sunk by U-boats, their utility lay in both their propaganda value and the number of Allied ships that had been tasked with pursuing these raiders around the world, taking them out of use in other theatres of the war. ${ }^{225}$

\subsection{THE NAVAL AUXILIARY}

The war at sea involved not only the great battleships of the era, the newly developed submarines and the armada of smaller warships, but a great range of ship types acting in a variety of support or auxiliary roles. This included tankers, colliers, trawlers, merchant vessels and liners, acting as troopships, hospital ships, minesweepers and commerce raiders. These roles also differed as between the belligerents, with the Allies, for example, making extensive use of liners as troopships, while Germany used what liners they had as commerce raiders and minelayers. Germany too relied heavily on colliers to supply coal to its widely distributed commerce raiders given the lack of German colonial ports. ${ }^{226}$

Britain, far more than any other belligerent State, activated a vast armada of vessels to help patrol its waters, especially in combating mine-laying and submarine activity which escalated until unrestricted. By war's end, the British Auxiliary patrol had consisted of nearly 4,000 vessels manned by nearly 540,000 officers and men. ${ }^{227}$ The vessels themselves were of a great variety - including fishing trawlers, yachts, drifters, whalers and motorboats. ${ }^{228}$ Trawlers in particular had been identified as useful for minesweeping and the Royal Naval Reserve Trawling Section had been created in 1910 to prepare for this role. ${ }^{229}$ The first minesweeping trawlers sunk were HMT Thomas W Irvin ${ }^{230}$ and HMT

\footnotetext{
223 Noppen (n35) 43-4.

224 Ibid. 46.

225 Ibid. 46.

226 Ibid. 8.

227 Archibald Hurd The Merchant Navy: Volume 1 (John Murray, 1921) 257.

228 Ibid. 255.

229 Cant and Dunkley (n151) 43.

230 With the loss of two crew. Wrecksite, <https://wrecksite.eu/wreck.aspx ?144903>.
} 
Crathie, ${ }^{231}$ while sweeping one the earliest minefields on 27 August 1914. At war's end, 815 Auxiliary vessels had been lost, including 289 to submarines and 225 to mines. 232

Germany also requisitioned many vessels as auxiliaries. The task of laying mines was often taken up by converted liners, merchant or fishing vessels. The mine-laying Königin Luise, for example, was a liner of the Hamburg America Line taken over by the German navy three days before the outbreak of war. ${ }^{233}$ Italy too mobilised its auxiliaries at the beginning of hostilities, though this amounted to only 52 fishing boats, tugs, yachts and steamers, used for its coastal patrol. ${ }^{234}$ Subsequently more were purchased from other nations.

\subsubsection{Troopships}

As a world war in the age of imperialism, there was significant troop movement, particularly those of Allied soldiers dispatched from the four corners of the British Empire. The troops that travelled the furthest were those of the Australian Imperial Force carried on a range of vessels, many of which were chartered by the Commonwealth of Australia on a variety of different terms. ${ }^{235}$ Liners, Royal Mail Steamers and aging warships were used, as were captured German vessels, such as the Pfalz, which was renamed HMAT 42 Barrara. ${ }^{236}$

Given the significant amount of Allied troop movements, from Canada, the US, Australia, New Zealand, South Africa and India, surprisingly few troopships were sunk. This was especially true at the beginning of the war, when no attempt appears to have been made to prevent the British Expeditionary Force landing on the continent, and an unsuccessful, though half-hearted attempt, at preventing Canadian troops landing late in $1914 .{ }^{237}$ As war progressed, however, sinking began to occur. While they were not sunk in great numbers, when they were, they were often sunk with great loss of life. The British Royal Edward was sunk off Turkey on 13 August 1915 after being hit by a torpedo fired by U14 with

\footnotetext{
231 With the loss of two crew. Wrecksite, <https://wrecksite.eu/wreck. aspx?237360>.

232 British Vessels Lost at Sea 1914-1918 (n155) 28-9.

233 Wrecksite, <http://www.wrecksite.eu/wreck.aspx?9543>.

234 Cernuschi (n39) 209.

235 Viduka (n12) 159.

236 Ibid.

237 Faulkner (n5) 16.
} 
the loss of at least 132 lives, though some estimates are as high as $935 .{ }^{238}$ The Anchor Line troopship Transylvania was sunk by U63 off Italy with the loss of 39 crew and 373 troops. ${ }^{239}$ Two French troopships were sunk with great loss of life; the Calvados, carrying an infantry unit, was torpedoed by $U 38$ on 4 November 1915 with the loss of 740 of those on board, ${ }^{240}$ and the Athos, carrying a contingent of Chinese Labour Corps, Senegalese Infantry and a small contingent of Cambodian troops, by U65 in the Mediterranean on 17 February 1917, with the loss of 754 lives. ${ }^{241}$ Two Italian troopships also sank with great loss of life. The Minas was torpedoed by $U 39$ on 15 February 1917 with the loss of 870 crew and soldiers $^{242}$ and the Verona was torpedoed by UC52 on 11 May 1918, killing 880 crew and soldiers. ${ }^{243}$ It was, however, with the sinking of the Italian troopship Principe Umberto that the greatest loss of life in a vessel sinking occurred. An Italian passenger and refrigerated cargo ship used as a troopship, the Principe Umberto was sunk in the Adriatic on 8 June 1916 by the Austro-Hungarian U5 with the loss of 1,650 of the 2,821 men aboard. ${ }^{244}$ It had been carrying the 55th Infantry regiment back from Albania to Italy at the time of its sinking.

Troopships were also sunk by accident. The Mendi, carrying members of the South African Labour Corps, who were to serve behind the lines in France, collided with another vessel and sank off the Isle of Wight, Britain, on 21 February 1917, taking 607 black South African servicemen and 39 crew with it. 245

When the US entered the war, more than two million US troops were transported to Europe. Many were taken in British ocean liners converted to troopships, including the Aquitania, Mauretania and Olympic. Ironically, many were transported in German ocean liners that had been interred at the beginning of the war, converted to troopships and renamed, including the largest ocean liner of the time, the Vaterland,

\footnotetext{
238 Ibid. 69. Wrecksite <http://www.wrecksite.eu/wreck.aspx?21090>.

239 Wrecksite <https://www.wrecksite.eu/wreck.aspx?37314>.

240 Henri Legoherel 'Submarine Warfare and Civilian Shipping on the Brittany Coast from Saint-Malo to Nantes' in Guérin et al. (n12) 38. Wrecksite $<$ http://www.wrecksite.eu/wreck.aspx?154553.

241 Wrecksite <http://www.wrecksite.eu/wreck.aspx?134938>.

242 Wrecksite <http://www.wrecksite.eu/wreck.aspx?153630>.

243 Wrecksite <http://www.wrecksite.eu/wreck.aspx?176997>.

244 Wrecksite <http://www.wrecksite.eu/wreck.aspx?142775>.

245 John Gribble and Jonathan Sharfman, 'The Wreck of SS Mendi (1917) as an Example of the Potential Transnational Significance of World War I Underwater Cultural Heritage' in Guérin et al. (n12) 78. Wrecksite <http://www. wrecksite.eu/wreck.aspx?1271>.
} 
which became the Leviathan. ${ }^{246}$ Only one troopship on route to the continent was sunk, the Tuscania, losing 166 soldiers and 44 crew.247 U-boats were much more successful when attacking troopships returning to America. Losses included the President Lincoln with the loss of 27 crew but no loss of troops, the Covington with the loss of seven men; the Antilles with the loss of 67 men; the Moldavia with the loss of 66 men, the Ticonderoga with the loss of 215 men and the Mount Vernon with the loss of 35 men. ${ }^{248}$

\subsubsection{Hospital Ships}

Given that the British were fighting on the continent and that its colonies sent troops from far afield, a number of passenger vessels were requisitioned to serve as hospital ships. Of the approximately 22 hospital ships sunk during the war, 16 were British or from one of its colonies (two Canadian and one Australian). Despite these being subject to the 1907 Hague Convention for the Adaptation to Maritime War of the Principles of the Geneva Convention, the German policy of unrestricted submarine warfare meant that they were targeted, and a number sunk by U-boats. The HMHS Glenart Castle, for example, was torpedoed by UC56, with the loss of 153 lives, ${ }^{249}$ the HMHS Rewa, torpedoed by U55 with the loss of only four lives, ${ }^{250}$ and the Australian-owned hospital ship HMS Warilda, sunk by UC49 with the loss of 123 lives. ${ }^{251}$ The greatest lives lost occurred when the HMHS Llandovery Castle, acting as a Canadian hospital ship, was torpedoed by U86 on 27 June 1918 with the loss of 248 lives. ${ }^{252}$

A number of hospital ships were sunk after hitting a mine. The $H M H S$ Anglia, returning to Britain with wounded, hit a mine laid by UC5 off Folkstone on the 17 November 1915. It sank within ten minutes, taking 133 soldiers and crew as well as a nurse with it. ${ }^{253}$ The Salta too hit a mine, and sank on 10 April 1917 with the loss of 176 lives. ${ }^{254}$ One of the more famous hospital ships sunk was the HMHS Britannic, sister ship to

\footnotetext{
246 Massie (n2) 762.

247 Ibid. Wrecksite <http://www.wrecksite.eu/wreck.aspx?10317>.

248 Ibid. 763.

249 Wrecksite <http://www.wrecksite.eu/wreck.aspx?10947>.

250 Wrecksite <https://www.wrecksite.eu/wreck.aspx?10544>.

251 Wrecksite <http://www.wrecksite.eu/wreck.aspx?1951>.

252 Wrecksite <http://www.wrecksite.eu/wreck.aspx?10268>.

253 Wrecksite <http://www.wrecksite.eu/wreck.aspx?3>.

254 Wrecksite <http://www.wrecksite.eu/wreck.aspx?1981>.
} 
the Titanic, after hitting a mine in Greek waters on 21 November 1916, with the loss of 30 lives.255 Other nations also lost hospital ships, including the Dutch Koningin Regentes, torpedoed by UB107 with the loss of seven lives, ${ }^{256}$ and the Italian Marechiaro after hitting a mine, with a loss estimate ranging from 33 to 200 lives. ${ }^{257}$

Hospital ships were also lost to storms and navigational errors contributed to by wartime limitations on lighting, such HMHS Rohilla, lost off Whitby on 30 October 1914 with the loss of 84 crew. ${ }^{258}$

\subsection{THE MERCHANT MARINE IN WAR}

The war had a significant impact on the merchant fleets of both belligerent and neutral nations, especially once Germany embarked on a strategy of unrestricted submarine warfare. This is reflected in the exploits of $U 35$ that, during a single mission, sank 23 merchant vessels; 12 British, four Italian, three Greek, two Norwegian, one American and one Danish. All but the British and Italian were neutral. ${ }^{259}$ It was, however, the merchant fleet of Britain that suffered the most. Merchant shipping losses began to increase in the months ending 1916 with 171 ships lost in September, 182 in October, 179 in November and 193 in December. In January 1917, 202 ships were lost. ${ }^{260}$ With unrestricted U-boat warfare being declared on 31 January, losses began to soar; with 291 in February, 355 in March and 458 in April. ${ }^{261}$ With the US entering the war, increased destroyer activity and the introduction of the convoy system, numbers began to drop. In May 1917, 357 merchant ships were lost, in June 352, in July 262, in August 201, in September 209 and in October 179. Losses by then were less than the 600,000 tons a month that the German Admiralty believed was necessary to collapse the British economy and war effort. ${ }^{262}$ The convoy system had proved to be very effective. The worst convoy loss was not due to U-boats, but to a surface attack by the German cruisers Bremse and Brummer, which sank nine

\footnotetext{
255 Wrecksite <http://www.wrecksite.eu/wreck.aspx?135787>.

256 Wrecksite <http://www.wrecksite.eu/wreck.aspx?70926>.

257 Wrecksite <http://www.wrecksite.eu/wreck.aspx?123264>.

258 Wrecksite <https://wrecksite.eu/wreck.aspx?1813>.

259 Salgado and Russo (n138) 29.

260 Faulkner (n5) 111.

261 Ibid. 121.

262 Ibid. 130 and 136.
} 
merchant ships and the two destroyers, HMS Strongbow and HMS Mary Rose, on 17 October 1917.263

A significant number of Scandinavian merchant vessels - Danish and Norwegian - were lost, in part because agreement was reached with Britain to requisition these. While they flew the British flag, they retained their Scandinavian ownership, and in many cases, their Scandinavian crews. The remains of 175 Danish and Norwegian wrecks lie in English waters alone. ${ }^{264}$

The German adoption of a restricted form of submarine warfare in early 1915 proved difficult to implement, and led to the sinking of passenger liners, and the death of US citizens, which would ultimately bring the US into the war. The first incident was the sinking of the British liner Falaba by $U 28$ on 28 March 1915 . While U28 initially gave the passengers time to escape, when a British armed trawler was sighted, the Falaba was torpedoed before disembarkation was completed, leading to the loss of 128 lives including that of a US citizen. ${ }^{265}$ It was, however the sinking of the Lusitania on 7 May 1915 that would eventually bring the US into the war. ${ }^{266}$ The Cunard liner Lusitania, and its sister ships Mauretania and Aquitania had been designed for possible use as armed auxiliary cruisers, but by May 1915, the Lusitania was the only one of the three that had not been requisitioned. When $U 20$ sighted the Lusitania, the captain used two British identification books that had it listed as a Royal Navy Reserve Merchant Cruiser and, considered to be a legitimate target, torpedoed it; 1,198 passengers and crew drowned, including 123 US citizens. ${ }^{267}$ While its sinking was celebrated as a significant success in Germany, British and the US reaction labelled the act as one of great brutality.

Later that year, on 19 August, the Arabic was sunk by U24 with the loss of 44 lives, including three Americans. ${ }^{268}$ The loss of American lives, particularly passengers on liners, was one of the catalysts for the US entering the war. Arguably, the last straw was the loss of the small Cunard liner Laconia, torpedoed by U50 with the loss of 12 lives

\footnotetext{
263 Massie (n2) 747; Faulkner (n5) 137.

264 Cant and Dunkley (n151) 45.

265 Delgado and Varmer (n113) 106.

266 Ibid.

267 Robert D Ballard Exploring the Lusitania (Weidenfield and Nicolson, 1995) 13. While numbers vary, the memorial at Old Head of Kinsale, Ireland lists 1,198. <http://www.maritimequest.com/misc_pages/monuments_memorials/ lusitania_memorial_ireland.htm>.

268 Delgado and Varmer (n113) 106.
} 
including two American women. ${ }^{269}$ Liners of other nations too suffered, including from indiscriminate mines. The Austrian liner Baron Gautsch hit an Austrian mine and sunk on 13 August 1914 with the loss of 177 of 336 on board. ${ }^{270}$

By the end of the war, Britain had lost 2,479 merchant vessels (totalling 7,759,090 gross tons) with the loss of 14,287 crew. ${ }^{271}$ Other belligerent States' merchant marines also suffered but not to the same extent as that of Britain. The French merchant marine lost about 3,200 men in 711 vessels totalling about 1,128,000 tons. ${ }^{272}$ Given its geographical position, the Dutch particularly suffered losses and, due to those, it suffered significant food shortages during the war. ${ }^{273}$ AustriaHungary lost 20 per cent of its merchant tonnage to mines and torpedoes alone, ${ }^{274}$ while Italian losses in the Adriatic and Mediterranean totalled approximately 860,792 gross tons. ${ }^{275}$

An oft forgotten loss in the merchant fleet was that of fishing vessels, and many were sunk with great loss of life. Britain, for example, lost 675 fishing vessels with the loss of 434 fishermen. ${ }^{276}$

\subsection{THE SCUTTLING}

The disintegration of law and order in Germany by the end of 1918 spread to the navy with a sailors' revolt that made naval operations impossible. Britain wanted the Germany navy either destroyed in battle or surrendered, but Britain's allies did not want the British fleet to be augmented by the surrender of German vessels and therefore preferred that the German fleet be interned. ${ }^{277}$ The armistice agreement, signed on 11 November 1918, provided that the German fleet was to be interred in Scapa Flow until the final peace treaty was signed.

\footnotetext{
269 Massie (n2) 710. Wrecksite <http://www.wrecksite.eu/wreck.aspx? $13710>$.

270 Zvonimir Freivogel (n92) 36. Wrecksite <http://www.wrecksite.eu/wreck. aspx?16808>.

271 British Vessels Lost at Sea 1914-1918 (n155) 162-3.

272 Moulin (n105) 65.

273 Will Bouwers 'Mapping Underwater Cultural Heritage: Exploring and

Presenting Underwater Cultural Heritage' in Guérin et al. (n12) 206.

274 Cernuschi (n39) 200.

275 Ibid. 209-10.

276 British Vessels Lost at Sea 1914-1918 (n155) 162-3.

277 Faulkner (n5) 162.
} 
By 21 November 1918, 74 ships had entered Scapa Flow, flanked by 370 predominantly British warships. Believing that the fleet would be seized by Britain, the Commanding Officer Rear Admiral Ludwig von Reuter, ordered the fleet to be scuttled. During the attempt to stop the scuttling, a German officer and seven crew were killed, and were the very last casualties of the war. Over a five-hour period, the majority of the German fleet sank in Scapa Flow. A few ships failed to sink or were towed and beached before they foundered. A week after the scuttling, the Treaty of Versailles was signed on 28 June 1919.278

The ships at Scapa Flow did not include any submarines; 176 U-boats were eventually delivered, while eight foundered on the journey across the North Sea, fortunately with no loss of life.279 The U-boats were then divided up between the various Allied nations, and all were destroyed except the 46 allotted to France. ${ }^{280}$

\subsection{THE EXTENT OF THE LOSSES}

The loss of ships was caused by a greater variety of circumstances than had ever existed before, given the rapid advances in technology, including the torpedo, the mine, the depth charge, aircraft and airships. In addition, ships were sunk in a range of circumstances from collision, ramming and scuttling to loss in action.

It is estimated that the Royal Navy lost 254 warships, 52 submarines ${ }^{281}$ and 815 auxiliary ships ${ }^{282}$ with the loss of more than 74,000 sailors and 15,300 merchant seamen. ${ }^{283}$ By the time of the armistice, the French navy had lost 132 ships and 11,388 men. ${ }^{284}$ By comparison, the Italian navy had

\footnotetext{
278 Massie (n2) 787-8.

279 Ibid. 781.

280 Ibid.

281 Only three were lost in English territorial waters (C29, D5 and E6), four in Scottish waters $(C 34, D 6, E 39$ and E49) and one in Welsh waters (H5). Karen E Walker and Steve J Webster, English Heritage Report Unknown Marine Assets and Landscape: Strategic Assessment of Submarines in English Waters (Report CA.Project.4132; Report.6655 Cotswold Archaeology, 2014) 15.

282 British Vessels Lost at Sea 1914-1918 (n155) 8 and 29.

283 Guérin et.al (n12) 10.

284 Moulin (n105) 83.
} 
lost a total of 66 vessels, including seven large ships and eight submarines. ${ }^{285}$ German losses were particularly noticeable in terms of its U-boat losses, with 178 lost, many with all their crew. 286

It is more than a century since each of these vessels sank. Over that century much has changed and how we value these wrecks now is not only a product of that history, but an expression of our values today.

285 Cernuschi (n39) 184.

286 McCartney (n153) 4. 